\title{
Analisa Laporan Keuangan Sebagai Dasar Penilaian Kondisi Kinerja Manajemen PT. Ultrajaya Milk Industry \& Trading Company Tbk.
}

\author{
Dwi Dayanti Oktavia ${ }^{1}$ \\ Desvilian Larasati Rachim² \\ Program Studi Manajemen \\ Sekolah Tinggi Ilmu Ekonomi Kertanegara Malang \\ dwidayanti8@gmail.com \\ liandesvi@gmail.com
}

\begin{abstract}
This research was conducted to determine the management performance of PT. Ultrajaya Milk Industry \& Trading Company, Tbk. The method used in the form of quantitative descriptive is by collecting, presenting, and analyzing data from the company using liquidity ratio and solvency analysis of the financial statements of PT. Ultrajaya Milk Industry \& Trading Company, Tbk. 2013, 2014, 2015, 2016 and 2017. Based on the research that has been done, it can be concluded that PT. Ultrajaya Milk Industry \& Trading Company, Tbk in 2013 - 2017 has a very good performance. Seen from the increase in the average number of Current Ratio for 5 years by 43\%, Quick Ratio of $43 \%$ and Cash Ratio of $40 \%$. The optimal performance of the company according to the calculation of liquidity ratios occurred in 2016 where there was a 100\% increase in each ratio. Based on the Solvability calculation for 5 years DTAR decreased by 2\%, DTER by 4\% and TIE experienced an increase of 158 times. Where this ratio figures prove that the company is very solvable. While the rentability ratio calculation shows that the company is able to generate profits even with a small percentage that is less than 50\%. The researcher also evaluates the financial management performance of PT. Ultrajaya Milk Industry \& Trading Company, Tbk. during 2013 - 2017 when compared to similar companies. And the results obtained are that PT. Ultrajaya Milk Industry \& Trading Company, Tbk has a superior performance than PT. Mayora Indah Tbk and PT. Indofood Sukses Makmur, Tbk. with the ratio of numbers always above the industry average
\end{abstract}

Keywords : Raw Material Costs, Labor Costs, Factory Overhead Costs

\section{Abstrak}

Penelitian ini dilakukan untuk mengetahui kinerja manajemen PT. Ultrajaya Milk Industry \& Trading Company, Tbk. Metode yang digunakan berupa kuantitatif deskriptif yaitu dengan cara mengumpulkan, menyajikan, dan menganalisis data dari perusahaan menggunakan analisa rasio likuiditas dan solvabilitas terhadap laporan keuangan PT. Ultrajaya Milk Industry \& Trading Company, Tbk. periode 2013, 2014, 2015, 2016 dan 2017. Berdasarkan penelitian yang telah dilakukan, dapat disimpulkan bahwa PT. Ultrajaya Milk Industry\& Trading Company, Tbk pada tahun 2013 - 2017 memiliki kinerja yang sangat baik. Terlihat dari kenaikan angka angka rata-rata Current Ratio selama 5 tahun sebesar 43\%, Quick Ratio sebesar 43\% dan Cash Ratio sebesar 40\%. Kinerja optimal perusahaan menurut perhitungan rasio likuiditas terjadi pada tahun 2016 dimana mengalami kenaikan $100 \%$ dari masing-masing rasio.Berdasarkan perhitungan Solvabilitas selama 5 tahun mengalami penurunan DTAR sebesar 2\%, DTER sebesar $4 \%$ dan TIE mengalami kenaikan http://jurnal.stiekma.ac.id/index.php/JAMIN 
rata-rata sebesar 158 kali.Dimana angka rasio ini membuktikan bahwa perusahaan sangat solvable.Sedangkan perhitungan rasio Rentabilitas menunjukkan bahwa perusahaan mampu menghasilkan laba walaupun dengan persentase yang kecil yaitu kurang dari $50 \%$. Peneliti juga melakukan penilaian kinerja manajemen keuangan PT. Ultrajaya Milk Industry\& Trading Company, Tbk. selama tahun 2013 - 2017 jika dibandingkan dengan perusahaan sejenis. Dan diperoleh hasil bahwa PT. Ultrajaya Milk Industry\& Trading Company, Tbk memiliki kinerja lebih unggul daripada PT. Mayora Indah Tbk dan PT. Indofood Sukses Makmur, Tbk. dengan angka rasio selalu di atas rata-rata industri.

Kata kunci : biaya bahan baku, biaya tenaga kerja, biaya overhead pabrik

\section{PENDAHULUAN}

Perkembangan ekonomi yang sangat pesat membuat para produsen di Indonesia yang bergerak dibidang makanan dan minuman lebih meningkatkan inovasinya agar bisa bertahan dan bersaing dengan produk-produk baru yang bermunculan. Salah satunya PT. Ultrajaya Milk Industry \& Trading Company Tbk. sebagai konsumen perusahaan minuman tersebut, saya ingin berfikir lebih kritis untuk mengikuti perkembangan informasi ekonomi yang terjadi pada PT. Ultrajaya Milk Industry \& Trading Company Tbk. Perkembangan informasi ekonomi bisa dilakukan dengan cara menganalisis laporan keuangan yang ada pada perusahaan tersebut. Laporan keuangan suatu perusahaan berfungsi untuk melaporkan kondisi keuangan dan kinerja perusahaan dalam menghasilkan laba.Kondisi keuangan pada perusahaan dapat digunakan oleh pihak manajemen untuk mengukur atau menilai kinerja perusahaan dalam memenuhi kewajiban yang harus dipenuhi.Laporan keuangan terdiri dari laporan neraca dan laba rugi, sehingga pihak yang berkepentingan seperti nasabah, investor, kreditur, dan pihak manajemen dapat mengetahui kekayaan aktiva dan pasiva yang dimiliki oleh perusahaan tersebut.Sedangkan, penilaian kinerja perusahaan bisa dianalisa menggunakan berbagai rasio, diantaranya Rasio Likuiditas dan Solvabilitas.Rasio Likuiditas sangatlah penting bagi suatu perusahaan karena dapat digunakan sebagai acuan untuk mengukur kemampuan perusahaan dalam memperoleh kewajiban keuangannya yang harus segera dipenuhi atau kemampuan perusahaan untuk memenuhi hutangnya pada saat ditagih. Rasio Solvabilitas juga berperan penting dalam analisa laporan keuangan karena berfungsi sebagai tolak ukur kemampuan perusahaan untuk memenuhi kewajiban keuangannya apabila perusahaan tersebut dilikuidasi baik kewajiban jangka pendek maupun jangka panjang.Maka dari itu, peneliti membuat rumusan masalah untuk menjawab beberapa pertanyaan:

1) Bagaimana Kinerja Manajemen PT. Ultrajaya Milk Industry \& Trading Company Tbk. pada data Bursa Efek Indonesia (BEI) selama periode 2013, 2014, 2015, 2016 dan 2017 berdasarkan Rasio Likuiditas, Solvabilitas, dan Rentabilitas?

2) Bagaimana Kinerja Manajemen Perusahaan PT. Ultrajaya Milk Industry \& Trading Company, Tbk. periode 2013, 2014, 2015, 2016 dan 2017 jika dibandingkan dengan perusahaan sejenisnya menggunakan analisis Rasio Likuiditas, Solvabilitas dan Rentabilitas? 


\section{METODE}

Penulisan penelitian ini menggunakan metode kuantitatif deskriptif untuk menguji teori tertentu dengan cara meneliti hubungan antarvariabel dengan cara mengumpulkan, menyajikan, dan menganalisis data dari perusahaan menggunakan analisa rasio keuangan terhadap laporan keuangan.

Penelitian dilakukan dengan mengambil data pada website Bursa Efek Indonesia (BEI) yaitu www.idx.co.id .Waktu yang diperlukan untuk menyusun penelitian ini dimulai pada bulan Oktober sampai Desember 2017.

\section{HASIL DAN PEMBAHASAN}

Penilaian Kinerja Manajenmen PT. Ultrajaya Milk Industry \& Trading Company Tbk. Menggunakan Rasio Keuangan.

\section{A. Rasio Likuiditas}

Rasio Likuiditas adalah suatu rasio keuangan yang menunjukkan kemampuan perusahaan dalam memenuhi kewajiban-kewajiban jangka pendeknya yang harus segera dipenuhi.Tabel 1 menggambarkan data-data yang diperlukan dalam perhitungan Rasio Likuiditas pada PT. Ultrajaya Milk Industry \& Trading Company Tbk. pada periode tahun $2013-2017$.

Rasio ini memiliki tiga macam perhitungan untuk mengukur likuiditas suatu perusahaan, antara lain:

1) Current Ratio (Rasio Lancar) Untuk menghitung rasio ini menggunakan rumus:

Current Ratio $=\times 100 \%$

2) Quick Ratio (Rasio Cepat)

Untuk menghitung rasio ini menggunakan rumus:

Quick Ratio (QR)=

3) Cash Ratio (Rasio Kas)

Untuk menghitung rasio ini menggunakan rumus:

mengukur kemampuan kas yang dimiliki perusahaan dalam memenuhi kewajibannya.

Cash Ratio $=$ 
Tabel 1. Perhitungan Rasio Likuiditas PT. Ultrajaya Milk Industry \& Trading Company Tbk.

\begin{tabular}{|c|c|c|c|c|c|}
\hline Rekening & 2013 & 2014 & 2015 & 2016 & $\begin{array}{c}2017 \\
\text { (dalam Jutaan Rp) }\end{array}$ \\
\hline Aktiva Lancar & $1,565,510,655,138$ & $1,642,101,746,819$ & $2,103,565,054,627$ & $2,874,821,874,013$ & $3,439,990$ \\
\hline Hutang Lancar & $633,794,053,008$ & $490,967,089,226$ & $561,628,179,393$ & $593,525,591,694$ & 820,625 \\
\hline Persediaan & $534,977,217,239$ & $714,411,455,060$ & $738,803,692,770$ & $760,534,170,292$ & 682,624 \\
\hline Kas dan Setara Kas & $611,624,871,676$ & $489,284,795,925$ & $849,122,582,559$ & $1,521,371,695,873$ & $2,120,400$ \\
\hline
\end{tabular}

Sumber: Laporan Neraca PT. Ultrajaya Milk Industry \& Trading Company Tbk. (Data telah diolah, 2018)

Tabel 2. Hasil Perhitungan Rasio Likuiditas PT. Ultrajaya Milk Industry \& Trading Company, Tbk.

\begin{tabular}{|c|c|c|c|c|c|c|}
\hline \multicolumn{2}{|r|}{ LIKUIDITAS } & \multicolumn{5}{|c|}{ Tahun } \\
\hline Rasio & Rumus & 2013 & 2014 & 2015 & 2016 & 2017 \\
\hline Current Ratio & Aktiva Lancar/Hutang Lancar & $247 \%$ & $334 \%$ & $375 \%$ & $484 \%$ & $419 \%$ \\
\hline Quick Ratio & Aktiva Lancar-Persediaan/Hutang Lancar & $163 \%$ & $189 \%$ & $243 \%$ & $356 \%$ & $336 \%$ \\
\hline Cash Ratio & Kas dan Setara Kas/Hutang Lancar & $97 \%$ & $100 \%$ & $151 \%$ & $256 \%$ & $258 \%$ \\
\hline
\end{tabular}

Sumber: Laporan Neraca PT. Ultrajaya Milk Industry \& Trading Company Tbk. (Data telah diolah, 2018) 


\section{1) Current Ratio}

Current Ratio PT. Ultrajaya Milk Industry \& Trading Company Tbk. pada tahun 2013 menunjukkan angka $247 \%$ yang artinya jumlah aktiva lancar sebanyak 2,5 kali hutang lancar atau setiap Rp. 1 kewajiban lancar akan dijamin oleh Rp 2,5 aktiva lancar atau 2,5:1 antara aktiva dan hutang lancar. Tahun 2014 Current Ratio meningkat pada angka 334\% yang artinya jumlah aktiva lancar sebanyak 3,3 kali atau setiap Rp. 1 kewajiban lancar akan dijamin oleh Rp 3,3 aktiva lancar atau 3,3:1 antara aktiva dan hutang lancar. Tahun 2015 Current Ratio meningkat lagi sebesar 374\%, yang artinya jumlah aktiva lancar sebanyak 3,8 kali atau setiap Rp. 1 kewajiban lancar akan dijamin oleh Rp. 3,8 aktiva lancar atau 3,8:1 antara aktiva dan hutang lancar. Tahun 2016 Current Ratio terbaik yakni sebanyak $484 \%$ yang artinya jumlah aktiva lancar sebanyak 4,8 kali atau setiap Rp. 1 kewajiban lancar akan dijamin oleh Rp. 4,8 aktiva lancar atau 4,8:1 antara aktiva dan hutang lancar. Namun pada tahun 2017, Current Ratio menurun menjadi $419 \%$ yang artinya jumlah aktiva lancar sebanyak 4,2 kali atau setiap Rp. 1 kewajiban lancar akan dijamin oleh Rp. 4,2 aktiva lancar atau 4,2:1 antara aktiva dan hutang lancar

Perhitungan di atas menunjukkan berapa kali aset lancar dapat membiayai hutang lancar perusahaan.Semakin tinggi rasio ini maka semakin baik kinerja perusahaan yang ditunjukkan.Menurut Kasmir (2008:143) standar industri current ratio adalah sebanyak 2 kali. Maka pada tahun 2013 sampai dengan tahun 2017 kinerja manajemen PT. Ultrajaya Milk Industry \& Trading Company Tbk. sangat baik, karena current ratio berada di atas angka 2 dan selalu meningkat setiap tahunnya.

\section{2) Quick Ratio}

Pada tahun 2013 hasil perhitungan QR sebanyak 163\%, artinya setiap Rp. 1 kewajiban lancar akan dijamin Rp. 1,6 aktiva lancar. Tahun 2014 QR meningkat lagi sebesar 189\%, artinya setiap Rp. 1 kewajiban lancar akan dijamin Rp. 1,9 aktiva lancar. Tahun 2015 Quick Ratio meningkat sebanyak 243\%, artinya setiap Rp. 1 kewajiban lancar akan dijamin Rp. 2,4 aktiva lancar. Tahun 2016 QR terbaik selama lima tahun sebesar 356,23\%, artinya setiap Rp. 1 kewajiban lancar akan dijamin Rp. 3,6 aktiva lancar. Sedangkan pada tahun 2017, nilai QR mengalami sedikit penurunan menjadi 336\%, yang berarti bahwa setiap Rp. 1 kewajiban lancar akan dijamin Rp. 3,4 aktiva lancar

Semakin tinggi nilai rasio ini maka menunjukkan semakin baik pula kinerja manajemen yang dicapai oleh perusahaan. Menurut Kasmir (2008:143) standar industri quick ratio adalah sebanyak 1,5 kali. Maka pada tahun 2013 sampai dengan tahun 2017 kinerja manajemen PT. Ultrajaya Milk Industry \& Trading Company Tbk. sangat baik, karena quick ratio berada di atas angka 1,5 dan selalu meningkat setiap tahunnya.

\section{3) Cash Ratio}

Cash Ratio pada tahun 2013 meningkat sebanyak 97\%, artinya setiap Rp. 1 kewajiban lancar akan dijamin Rp. 0,97 aktiva lancar. Pada tahun 2014 PT. Ultrajaya Milk 
Industry \& Trading Company Tbk. CR menunjukkan angka 100\%, artinya setiap Rp. 1 kewajiban lancar akan dijamin Rp. 1 aktiva lancar. Tahun 2015 CR meningkat kembali 151\%, artinya setiap Rp. 1 kewajiban lancar akan dijamin Rp. 1,5 aktiva lancar. Sedangkan tahun 2016 PT. Ultrajaya Milk Industry \& Trading Company Tbk. CR terbaik sebanyak 256\%, artinya setiap Rp. 1 kewajiban lancar akan dijamin Rp. 2,6 aktiva lancar. Dan mengalami kenaikan di tahun 2017 nilai CR sebesar 258\%, artinya setiap Rp. 1 kewajiban lancar akan dijamin Rp. 2,6 aktiva lancar

Menurut Kasmir (2008:143), standar industri cash ratio adalah sebesar 50\%, artinya semakin tinggi rasio ini maka semakin baik kinerja manajemen yang dilakukan oleh perusahaan. Maka pada tahun 2013 sampai dengan tahun 2017 kinerja manajemen PT. Ultrajaya Milk Industry \& Trading Company Tbk. sangat baik, karena cash ratio berada di atas 1 dan selalu meningkat setiap tahunnya.

\section{B. Rasio Solvabilitas}

Rasio Solvabilitas adalah rasio yang menunjukkan kemampuan perusahaan dalam memenuhi segala kewajibannya baik jangka pendek maupun jangka panjang apabila perusahaan dilikuidasi.Tabel 2 menggambarkan data-data yang diperlukan dalam perhitungan Rasio Solvabilitas pada PT. Ultrajaya Milk Industry \& Trading Company Tbk. pada periode tahun 2013 2017.

Rasio ini memiliki tiga macam perhitungan untuk mengukur solvabilitas suatu perusahaan, antara lain:

1) Debt to Total Aset Ratio

Untuk menghitung rasio ini menggunakan rumus:

Debt Total to Asset Ratio (DTAR) =

2) Debt to Total Equity Ratio

Untuk menghitung rasio ini menggunakan rumus:

Debt to Total Equity Ratio (DTER)=

3) Times Interest Earned

Untuk menghitung rasio ini menggunakan rumus:

TIE: 
Tabel 3. Perhitungan Rasio Solvabilitas PT. Ultrajaya Milk Industry \& Trading Company Tbk.

\begin{tabular}{lrrrrr}
\hline \multicolumn{1}{c}{ Rekening } & \multicolumn{1}{c}{$\mathbf{2 0 1 3}$} & \multicolumn{1}{c}{$\mathbf{2 0 1 4}$} & \multicolumn{1}{c}{$\mathbf{2 0 1 5}$} & \multicolumn{1}{c}{$\mathbf{2 0 1 7}$} & 2016 \\
(dalam Jutaan Rp.) \\
\hline Total Aktiva & $2,811,620,982,147$ & $2,917,083,567,355$ & $3,539,995,910,248$ & $4,239,199,641,365$ & $5,186,940$ \\
Total Hutang & $796,474,448,056$ & $651,985,807,625$ & $742,490,216,326$ & $749,966,146,582$ & 978,185 \\
Modal Sendiri & $2,015,146,534,086$ & $2,265,097,759,730$ & $2,797,505,693,922$ & $3,489,233,494,783$ & $4,208,755$ \\
Laba Sebelum Bunga \& & $423,195,023,125$ & $374,126,536,835$ & $692,865,656,136$ & $888,986,639,228$ & 959,334 \\
Pajak & $7,955,069,915$ & $4,063,182,474$ & $2,314,561,134$ & $2,057,013,064$ & 1,498 \\
Bunga & & & &
\end{tabular}

Sumber: Laporan Laba Rugi PT. Ultrajaya Milk Industry \& Trading Company Tbk. (Data telah diolah, 2018)

Tabel 4. Hasil Perhitungan Rasio Solvabilitas PT. Ultrajaya Milk Industry \& Trading Company Tbk.

\begin{tabular}{ccccccc}
\hline \multicolumn{2}{l}{ SOLVABILITAS } & \multicolumn{5}{c}{ Tahun } \\
\hline Rasio & \multicolumn{1}{c}{ Rumus } & $\mathbf{2 0 1 3}$ & $\mathbf{2 0 1 4}$ & $\mathbf{2 0 1 5}$ & $\mathbf{2 0 1 6}$ & $\mathbf{2 0 1 7}$ \\
\hline DTAR & Total Hutang/Total Aktiva & $28 \%$ & $22 \%$ & $21 \%$ & $18 \%$ & $19 \%$ \\
DTER & Total Hutang/Modal Sendiri & $40 \%$ & $29 \%$ & $27 \%$ & $21 \%$ & $23 \%$ \\
TIE & EBIT/Bunga & 55 & 92 & 299 & 453 & 685 \\
\hline
\end{tabular}

Sumber: Laporan Laba Rugi PT. Ultrajaya Milk Industry \& Trading Company Tbk. (Data telah diolah, 2018) 


\section{Debt to Total Asset Ratio}

Pada tahun 2013 Debt to Total Asset Ratio menurun 28\%, artinya bahwa setiap Rp. 100,- pendanaan perusahaan Rp. 28,- dibiayai dengan utang dan Rp. 72,- disediakan oleh pemegang saham. Tahun 2014 Debt to Total Asset Ratio menurun sebanyak 22\%, artinya bahwa setiap Rp. 100,- pendanaan perusahaan Rp. 22,- dibiayai dengan utang dan Rp. 78,disediakan oleh pemegang saham.Tahun 2015 DTAR menglami penurunan sebesar 21\%, artinya bahwa setiap Rp. 100,- pendanaan perusahaan Rp. 21,- dibiayai dengan utang dan Rp. 79,- disediakan oleh pemegang saham. Selama lima periode, pada tahun 2016 Debt to Total Asset Ratio menunjukkan angka terendah yaitu 18\%, artinya bahwa setiap Rp. 100,pendanaan perusahaan Rp. 18,- dibiayai dengan utang dan Rp. 82,- disediakan oleh pemegang saham. Dan pada tahun 2017 Debt to Total Asset Ratio menunjukkan angka yaitu $19 \%$, artinya bahwa setiap Rp. 100,- pendanaan perusahaan Rp. 19,- dibiayai dengan utang dan Rp. 81,- disediakan oleh pemegang saham.

Semakin rendah rasio ini menunjukkan bahwa semakin baik keadaan kinerja perusahaan. Menurut Kasmir (2004:164), "standar industri untuk Debt to Total Asset Ratio adalah sebesar 35\%". Maka pada tahun 2013 sampai dengan tahun 2017 kinerja manajemen PT. Ultrajaya Milk Industry \& Trading Company Tbk. sangat baik, karena Debt to Total Asset Ratio berada di bawah angka 1 dan selalu menurun setiap tahunnya.

\section{2) Debt to Total Equity Ratio}

Pada tahun 2013 Debt To Equity Ratio mengalami penurunan 40\%., artinya jumlah kewajiban 40\% dari kekayaan bersih. Tahun 2014 Debt To Equity Ratio menunjukkan angka 29\%., artinya jumlah kewajiban 29\% dari kekayaan bersih. Tahun 2015 Debt To Equity Ratio sebesar 27\%., artinya jumlah kewajiban $27 \%$ dari kekayaan bersih. Selama lima periode, tahun 2016 memiliki Debt To Equity Ratio terendah yaitu 21\%., artinya jumlah kewajiban 21\% dari kekayaan bersih. Dan pada tahun 2017 Debt To Equity Ratio sebesar 23\%, artinya jumlah kewajiban $23 \%$ dari kekayaan bersih

Semakin tinggi rasio Debt To Equity Ratio menunjukkan kinerja yang buruk bagi perusahaan, sehingga perusahaan harus berusaha agar nilai rasio ini rendah. Menurut Kasmir (2008:164), "standar industri Debt To Equity Ratio yaitu 90\%". Maka pada tahun 2013 sampai dengan tahun 2017 kinerja manajemen PT. Ultrajaya Milk Industry \& Trading Company Tbk. sangat baik, karena Debt to Total Asset Ratio berada di bawah $90 \%$ dan selalu menurun setiap tahunnya.

\section{3) Times Interest Earned}

Times Interest RatioPT. Ultrajaya Milk Industry \& Trading Company Tbk.tahun 2013 TIE 55 kali. Artinya kemampuan perusahaan untuk membayar bunga liabilitas jangka panjang dijamin sebanyak 55 kali oleh keuntungan perusahaan. Tahun 2014 TIE menunjukkan angka 92 kali. Artinya kemampuan perusahaan untuk membayar bunga liabilitas jangka panjang dijamin sebanyak 92 kali oleh keuntungan perusahaan.Tahun 
2015 mengalami peningkatan pesat sebanyak 299 kali.Artinya kemampuan perusahaan untuk membayar bunga liabilitas jangka panjang dijamin sebanyak 299 kali oleh keuntungan perusahaan.Tahun 2016 TIE menunjukkan angka 432 kali. Artinya kemampuan perusahaan untuk membayar bunga liabilitas jangka panjang dijamin sebanyak 432 kali oleh keuntungan perusahaan.Dan peningkatan terbaik terjadi pada tahun 2017 dengan angka TIE sebesar 685 kali yang artinya kemampuan perusahaan untuk membayar bunga liabilitas jangka panjang dijamin sebanyak 685 kali oleh keuntungan perusahaan.

Menurut Kasmir (2008:164), "standar industri untuk rasio ini adalah sebesar 10 kali. Semakin tinggi rasio ini maka semakin baik kinerja manajemen yang ditunjukkan oleh perusahaan".Maka pada tahun 2013 sampai dengan tahun 2017 kinerja manajemen PT. Ultrajaya Milk Industry \& Trading Company Tbk. sangat baik, karena times interest earned berada jauh di atas angka 10 dan selalu meningkat setiap tahunnya.

\section{Rasio Rentabilitas}

Rasio yang digunakan untuk mengukur seberapa besar kemampuan perusahaan menghasilkan laba dalam hubungannya dengan penjualan, aktiva maupun laba dan modal sendiri.Tabel 6 menggambarkan data-data yang diperlukan dalam perhitungan Rasio Rentabilitas pada PT. Ultrajaya Milk Industry \& Trading Company Tbk. pada periode tahun 2013 - 2017.

Rasio profitabilitas terdiri atas :

1)

$\operatorname{Margin}(\mathrm{NPM})$

Untuk menghitung rasio ini, dapat digunakan rumus :

Net Profit Margin $=$

2)

Margin (GPM)

Untuk menghitung rasio ini, dapat digunakan rumus :

Gross Profit Margin =

3)

Return On Total Assets (ROA)

Untuk menghitung rasio ini, dapat digunakan rumus :

$$
\mathrm{ROA}=\times 100 \%
$$

4)

Return On Equity (ROE)

Untuk menghitung rasio ini, dapat digunakan rumus :

$$
\mathrm{ROE}=\mathrm{x} 100 \%
$$

5)

Return On Investment (ROI)

Untuk menghitung rasio ini, dapat menggunakan rumus :

$$
\mathrm{ROI}=x 100 \%
$$

Net Profit

Gross Profit

Rate of

Rate of

Rate of 
Menurut Kasmir (2008) dalam buku Analisis Laporan Keuangan dapat diketahui bahwa standar insutri dari kelima rasio tersebut sebagai berikut:

Tabel 5. Standar Industri Rasio Profitabilitas (Rentabilitas)

\begin{tabular}{clc}
\hline No. & \multicolumn{1}{c}{ Jenis Rasio } & Standar Industri \\
\hline 1. & Net Profit Margin (NPM) & $20 \%$ \\
2. & Gross Profit Margin (GPM) & $30 \%$ \\
3. & Rate of Return On Total Assets (ROA) & $30 \%$ \\
4. & Rate of Return On Equity (ROE) & $40 \%$ \\
5. & Rate of Return On Investment (ROI) & $30 \%$ \\
\hline
\end{tabular}

Sumber: Kasmir (2008) 
Tabel 6. Perhitungan Rasio Rentabilitas PT. Ultrajaya Milk Industry \& Trading Company Tbk.

\begin{tabular}{lrrrrr}
\hline \multicolumn{1}{c}{ Rekening } & $\mathbf{2 0 1 3}$ & $\mathbf{2 0 1 4}$ & $\mathbf{2 0 1 5}$ & $\mathbf{2 0 1 6}$ & $\begin{array}{r}\mathbf{2 0 1 7} \\
\text { (dalam Jutaan Rp,) }\end{array}$ \\
\hline EAT & $325,127,420,664$ & $283,360,914,211$ & $523,100,215,029$ & $709,825,635,742$ & 711,681 \\
Penjualan & $3,460,231,249,075$ & $3,916,789,366,423$ & $4,393,932,684,171$ & $4,685,987,917,355$ & $4,879,559$ \\
Laba Kotor & $1,013,783,120,476$ & $936,989,906,765$ & $1,382,489,122,282$ & $1,633,104,908,233$ & $1,822,878$ \\
EBIT & $423,195,023,125$ & $374,126,536,835$ & $692,865,656,136$ & $888,986,639,228$ & 959,334 \\
Total Aktiva & $2,811,620,982,147$ & $2,917,083,567,355$ & $3,539,995,910,248$ & $4,239,199,641,365$ & $5,186,940$ \\
Ekuitas Pemegang saham & $2,015,146,534,086$ & $2,265,097,759,730$ & $2,797,505,693,922$ & $3,489,233,494,783$ & $4,208,755$
\end{tabular}

Sumber: Laporan Neraca \& Laba Rugi PT. Ultrajaya Milk Industry \& Trading Company Tbk. (Data telah diolah, 2018)

Tabel 7. Hasil Perhitungan Rasio Rentabilitas PT. Ultrajaya Milk Industry \& Trading Company Tbk.

\begin{tabular}{|c|c|c|c|c|c|c|}
\hline \multicolumn{2}{|r|}{ RENTABILITAS } & \multicolumn{5}{|c|}{ Tahun } \\
\hline Rasio & Rumus & 2013 & 2014 & 2015 & 2016 & 2017 \\
\hline NPM & EAT/Penjualan & $9 \%$ & $7 \%$ & $12 \%$ & $15 \%$ & $15 \%$ \\
\hline GPM & Laba Kotor/Penjualan & $29 \%$ & $24 \%$ & $31 \%$ & $35 \%$ & $37 \%$ \\
\hline ROA & EBIT/Total Aktiva & $16 \%$ & $13 \%$ & $20 \%$ & $21 \%$ & $18 \%$ \\
\hline ROI & EAT/Total Aktiva & $12 \%$ & $10 \%$ & $15 \%$ & $17 \%$ & $14 \%$ \\
\hline ROE & EAT/Ekuitas Pemegang Saham & $16 \%$ & $13 \%$ & $19 \%$ & $20 \%$ & $17 \%$ \\
\hline
\end{tabular}

Sumber: Laporan Neraca \& Laba Rugi PT. Ultrajaya Milk Industry \& Trading Company Tbk. (Data telah diolah, 2018) 


\section{1) Net Profit Margin (NPM)}

Pada tahun 2013 NPM mulai mengalami penurunan sebanyak 9\% yang artinya setiap rupiah penjualan dapat menghasilkan Rp. 9,- dari laba bersih setelah pajak. Tahun 2014 NPM menunjukkan angka 7\% yang artinya setiap rupiah penjualan dapat menghasilkan Rp. 7,- dari laba bersih setelah pajak. Tahun 2015 NPM meningkat 12\% yang artinya setiap rupiah penjualan dapat menghasilkan Rp. 12,- dari laba bersih setelah pajak. Tahun 2016 dan 2017 memiliki nilai NPM yang sama yaitu 15\% yang artinya setiap rupiah penjualan dapat menghasilkan Rp. 15,- dari laba bersih setelah pajak.

Menurut Kasmir (2008:200), "semakin tinggi Net Profit Margin semakin baik operasi suatu perusahaan". Selama tahun 2013 - 2017, Net Profit Margin PT. Ultrajaya Milk Industry \& Trading Company, Tbk. dibawah standar rata-rata industri sebesar $20 \%$, sehingga kinerja perusahaan ini kurang baik dalam beroperasi.

\section{2) Gross Profit Margin (GPM)}

Pada tahun 2013 GPM 29\%.Tahun 2014 GPM sebesar 24\%.Tahun 2015 GPM meningkat sebesar 31\%. Tahun 2016 GPM 35\%. Dan tahun 2017 nilai GPM mencapai angka terbaik sebesar 37\%.dapat dilihat bahwa kondisi perusahaan masih cukup baik dalam menekankan harga pokok penjualan terhadap penjualan dikarenakan nilai GPM meningkat setiap tahunnya.

Menurut Syamsuddin (2009:61), "Semakin besar Gross Profit Margin semakin baik keadaan operasi perusahaan, karena hal ini menunjukkan bahwa harga pokok penjualan relatif lebih rendah dibandigkan dengan sales, demikian pula sebaliknya, semakin rendah Gross Profit Margin semakin kurang baik operasi perusahaan". Selama tahun 2015 hingga tahun 2017 PT. Ultrajaya Milk Industry \& Trading Company Tbk. bahwa kinerja perusahaan baik karena diatas standar industri 30\%, sehingga perusahaan dapat berproduksi secara efisien karena mampu mengendalikan biaya produksi. Sedangkan pada tahun 2013 - 2014 kinerja perusahaan tersebut kurang baik karena masih dibawah standar industri $30 \%$.

\section{3) Return On Asset (ROA)}

Pada tahun 2013 ROA 16\%.Tahun 2014 memiliki ROA terendah sebanyak 13\%.Sedangakan tahun 2015 meningkat sebanyak 20\%.Tahun 2016 ROA menjadi 21\%. Dan pada tahun 2017 mengalami penurunan menjadi 18\%

Menurut Kasmir (2008:203), "semakin besar nilai ROA berarti suatu perusahaan mempunyai kinerja yang bagus dalam menghasilkan laba bersih untuk pengembalian total aktiva yang dimiliki sehingga berpengaruh terhadap harga saham, yaitu harga saham akan naik". Pada tahun 2013 - 2017 PT. Ultrajaya Milk Industry \& Trading Company, Tbk.nilai ROA dibawah standar industri 30\%, sehingga kinerja perusahaan kurang baik karena belum sepenuhnya perusahaan mampu mengembalikan aktiva yang digunakan untuk operasi dalam menghasilkan laba. 


\section{4) Return On Investment (ROI)}

Pada tahun 2013 nilai ROA sebesar 12\%.Tahun 2014 memiliki nilai ROA terendah yakni 10\%. Sedangkan tahun 2015 meningkat 15\% dan tahun 2016 memiliki nilai ROA tertinggi sebesar 17\% dan di tahun 2017 mengalami penurunan nilai ROI sebesar 14\%.

Menurut Syafri (2008:63), "semakin tinggi rasio ini semakin baik keadaan suatu perusahaan. Return On Investment merupakan rasio yang menunjukkan berapa besar laba bersih diperoleh perusahaan bila diukur dari nilai aktiva". Selama tahun $2013-$ 2017 nilai ROA PT. Ultrajaya Milk Industry \& Trading Company, Tbk. dibawah standar industri 30\%, sehingga kinerja perusahaan kurang baik karena perusahaan belum sepenuhnya mampumenghasilkan keuntungan dengan jumlah aktiva yang dimiliki dalam perusahaan tersebut.

\section{5) Return On Equity (ROE)}

Pada tahun 2013 nilai ROE sebesar 16\%.Tahun 2014 memiliki nilai ROE terendah 13\%.Sedangkan tahun 2015 nilai ROE mengalami kenaikan sebesar 19\%.Tahun 2016 ROA tertinggi sebesar sebanyak 20\%.Dan pada tahun 2017 mengalami penurunan sebesar $17 \%$.

Menurut Kasmir (2008:205), "Standar rata-rata industri untuk ROE adalah 40\%". Pada PT. Ultrajaya Milk Industry \& Trading Company, Tbk. selama tahun 2013, 2014, 2015, 2016 dan 2017 mempunyai kinerja yang kurang baik karena masih dibawah standar industri. Namun masih bisa menghasilkan laba untuk perusahaan walaupun dengan persentase yang sangat kecil.

Penilaian Kinerja Manajemen PT. Ultrajaya Milk Industry \& Trading Company, Tbk. Menggunakan Rasio Keuangan jika Dibandingkan dengan Perusahaan Sejenisnya.

Kinerja suatu perusahaan dapat dinilai baik apabila ada pembanding dari perusahaan sejenis.Penilaian perusahaan tersebut menggunakan Cross Sectional Approach (mengetahui kondisi perusahaan jika dibandingkan dengan rasio industri).Perusahaan Manufaktur yang digunakan sebagai pembanding PT. Ultrajaya Milk Industry \& Trading Company, Tbk adalah PT. Mayora Indah, Tbk. dan PT. Indofood Sukses Makmur, Tbk. Hasil rasio perbandingan dapat dilihat sebagai berikut:

\section{1) Rasio Likuiditas}

Rasio Likuiditas adalah suatu rasio keuangan yang menunjukkan kemampuan perusahaan dalam memenuhi kewajiban-kewajiban jangka pendeknya yang harus segera dipenuhi.Pada prinsipnya, semakin tinggi rasio likuiditas semakin baik kemampuan perusahaan dalam memenuhi kewajiban jangka pendeknya.Penulis mengambil hasil perhitungan Current Ratio sebagai contoh perbandingan rasio dari masing-masing perusahaan pada tahun $2013-2017$. 
Tabel 8. Hasil Perhitungan Rasio Likuiditas PT. Ultrajaya Milk Industry \& Trading Company, Tbk. dengan perusahaan pembanding tahun 2013-2017

\begin{tabular}{lcrrrrr}
\hline \multicolumn{1}{c}{ Rasio Likuiditas } & \multicolumn{5}{c}{ Current Ratio (\%) } \\
\multicolumn{1}{c}{ Perusahaan } & $\mathbf{2 0 1 3}$ & $\mathbf{2 0 1 4}$ & $\mathbf{2 0 1 5}$ & $\mathbf{2 0 1 6}$ & $\mathbf{2 0 1 7}$ \\
\hline PT. Ultrajaya Milk Industry \& Trading & 247 & 334 & 375 & 484 & 419 \\
Company Tbk. & 240 & 209 & 237 & 225 & 239 \\
PT. Mayora indah Tbk. & 167 & 181 & 171 & 151 & 150 \\
PT. Indofood Sukses Makmur Tbk & $\mathbf{2 1 9}$ & $\mathbf{2 4 1}$ & $\mathbf{2 6 1}$ & $\mathbf{2 3 0}$ & $\mathbf{2 6 9}$ \\
Rata-rata & &
\end{tabular}

Sumber: Laporan Keuangan PT. Ultrajaya Milk Industry \& Trading Company, Tbk. (data delah diolah, 2018)

Berdasarkan tabel 4.10, diketahui bahwa pada tahun 2013 - 2016 PT. Ultrajaya Milk Industry \& Trading Company, Tbk memiliki nilai CR yang unggul dibandingkan perusahaan lainnya. Jadi, dapat disimpulkan bahwa kinerja PT. Ultrajaya Milk Industry \& Trading Company, Tbk selama tahun 2013 - 2017 mempunyai kinerja yang baik karena berada di atas rata-rata industri. Dari hasil perhitungan di atas, kemampuan perusahaan dalam menjamin hutang lancar dengan aktiva lancar perusahaan sangat baik, terutama PT. Ultrajaya Milk Industry \& Trading Company Tbk dan PT. Mayora Indah Tbk. Hal tersebut dikarenakan nilai CR secara keseluruhan dari tahun 2013 hingga 2017 berada di atas 200\%. Sedangkan PT. Indofood Sukses Makmur Tbk. Masih belum optimal dalam menjamin hutang lancar perusahaannya.

\section{2) Rasio Solvabilitas}

Rasio Solvabilitas adalah rasio yang menunjukkan kemampuan perusahaan dalam memenuhi segala kewajibannya baik jangka pendek maupun jangka panjang apabila perusahaan dilikuidasi.Perusahaan yang mempunyai aktiva/kekayaan yang cukup untuk membayar semua hutang-hutangnya disebut perusahaan yang solvable, sedang yang tidak disebut insolvable. Perusahaan yang solvable belum tentu likuid, demikian juga sebaliknya yang insolvable belum tentu likuid. Penulis mengambil hasil perhitungan Debt to Total Asset Ratio sebagai contoh perbandingan rasio dari masing-masing perusahaan pada tahun $2013-2017$. 
Tabel 9. Hasil Perhitungan Rasio Solvabilitas PT. Ultrajaya Milk Industry \& Trading Company, Tbk. dengan perusahaan pembanding tahun 2013-2017

\begin{tabular}{lcccccc}
\multicolumn{1}{c}{ Rasio Solvabilitas } & \multicolumn{5}{c}{ Debt to Total Asset Ratio (\%) } \\
\multicolumn{1}{c}{ Perusahaan } & \multicolumn{5}{c}{ Tahun } \\
& 2013 & 2014 & 2015 & 2016 & 2017 \\
\hline $\begin{array}{l}\text { PT. Ultrajaya Milk Industry \& Trading Company } \\
\text { Tbk. }\end{array}$ & 28 & 22 & 21 & 18 & 19 \\
PT. Mayora indah Tbk. & 59 & 60 & 54 & 28 & 51 \\
PT. Indofood Sukses Makmur Tbk & 51 & 52 & 53 & 47 & 47 \\
Rata-rata & 46 & 45 & 43 & 31 & 39 \\
\hline
\end{tabular}

Sumber: Laporan Keuangan PT. Ultrajaya Milk Industry \& Trading Company, Tbk. (data delah diolah, 2018)

Berdasarkan tabel 9, diketahui bahwa pada tahun 2013 - 2017, nilai Debt to Total Asset Ratio PT. Ultrajaya Milk Industry \& Trading Company, Tbk memiliki posisi yang unggul dan stabil jika dibandingkan dengan perusahaan lainnya. Hal tersebut terbukti dari hasil perhitungan DTAR yang berada di bawah rata-rata industri.Semakin rendah rasio ini menunjukkan bahwa semakin baik keadaan kinerja perusahaan. Jadi, dapat disimpulkan bahwa kinerja PT. Ultrajaya Milk Industry \& Trading Company, Tbk sangat baik sehingga perusahaan mampu menutupi hutang dengan aktiva yang dimiliki, karena semakin kecil rasionya semakin aman (solvable).Sedangkan PT. Mayora Indah serta PT. Indofood Sukses Makmur, kinerjanya masih kurang baik karena masih di atas rata-rata industri, sehingga perusahaan kurang bisa menutupi hutangnya menggunakan aktiva yang dimiliki oleh masing-masing perusahaan (tidak solvabel).

\section{3) Rasio Rentabilitas}

Rasio ini disebut juga sebagai rasio profitabilitas. Menurut Kasmir (2014:196), "Rasio Profitabilitas merupakan rasio untuk menilai kemampuan perusahaan dalam mencari keuntungan, rasio ini juga memberikan ukuran tingkat efektifitas manajemen suatu perusahaan. Hal ini ditunjukkan oleh laba yang dihasilkan dari penjualan dan pendapatan investasi.Pada dasarnya penggunaan rasio ini yakni menunjukkan tingkat efisiensi perusahaan.Penulis mengambil hasil perhitungan Return On Total Asset sebagai contoh perbandingan rasio dari masing-masing perusahaan pada tahun $2013-2017$. 
Tabel 10. Hasil Perhitungan Rasio Solvabilitas PT. Ultrajaya Milk Industry \& Trading Company, Tbk. dengan perusahaan pembanding tahun 2013-2017

\begin{tabular}{lccccc}
\multicolumn{1}{c}{ Rasio Rentabilitas } & \multicolumn{5}{c}{ Return On Total Asset (\%) } \\
\multicolumn{1}{c}{ Perusahaan } & $\mathbf{2 0 1 3}$ & $\mathbf{2 0 1 4}$ & $\mathbf{2 0 1 5}$ & $\mathbf{2 0 1 6}$ & $\mathbf{2 0 1 7}$ \\
\hline $\begin{array}{l}\text { PT. Ultrajaya Milk Industry \& Trading Company } \\
\text { Tbk. }\end{array}$ & 16 & 13 & 20 & 21 & 18 \\
PT. Mayora indah Tbk. & 13 & 9 & 16 & 4 & 16 \\
PT. Indofood Sukses Makmur Tbk & 9 & 8 & 8 & 10 & 10 \\
$\quad$ Rata-rata & $\mathbf{1 3}$ & $\mathbf{1 0}$ & $\mathbf{1 5}$ & $\mathbf{1 2}$ & $\mathbf{1 5}$ \\
\hline
\end{tabular}

Sumber: Laporan Keuangan PT. Ultrajaya Milk Industry \& Trading Company, Tbk. (data delah diolah, 2018)

Berdasarkan tabel 10, diketahui bahwa pada tahun 2013 - 2017 PT. Ultrajaya Milk Industry \& Trading Companymemiliki nilai rasio di atas rata-rata dibanding dengan PT. Mayora Indah Tbk, dan PT. Indofood Sukses Makmur, Tbk. Hal ini membuktikan bahwa perusahaan Ultrajaya Milk Industry \& Tradning Company mampu mencari keuntungan dari kemampuan netto atau laba bersih per rupiah penjualan. Semakin besar angka rasio ini maka semakin besar keuntungan netto dari setiap satuan uang penjualan, sehingga kinerja yang dimiliki perusahaan tersebut tergolong sangat baik karena selama 5 tahun selalu di atas rata-rata industri. Sedangkan 2 perusahaan pembanding masih dalam kondisi yang kurang baik.Karena persentase keuntungan yang mampu dihasilkan oleh kedua perusahaan tersebut sangat kecil dan dibawah rata-rata industry.

\section{SIMPULAN}

Berdasarkan penelitian yang telah peneliti lakukan, dapat diperoleh kesimpulan sebagai berikut:

1. Berdasarkan rasio likuiditas yang meliputi perhitungan Current Ratio, Quick Ratio, dan Cash Ratio, dapat disimpulkan bahwa kinerja PT. Ultrajaya Milk Industry \& Trading Company, Tbk. pada tahun 2013 - 2017 sangat baik. Terlihat dari semua hasil rasio likuiditas yang berada di atas $100 \%$ yang berarti mampu menjamin hutang lancar dengan aktiva lancar secara keseluruhan.

2. Berdasarkan rasio solvabilitas yang meliputi perhitungan Debt to Assets Ratio, Debt to Equity Ratio dan Time Interest Ratio, dapat disimpulkan bahwa kinerja PT. Ultrajaya Milk Industry \& Trading Company, Tbk. pada tahun 2013 - 2017 dalam kondisi solvable yang artinya perusahaan mampu menjamin hutang jangka panjangnya secara keseluruhan.

3. Dan berdasarkan rasio rentabilitas yang meliputi perhitungan Net Profit Margin, Gross Profit Margin, ROA, ROE, dan ROI dapat disimpulkan bahwa kinerja PT. Ultrajaya Milk Industry \& Trading Company, Tbk. cukup baik karena perusahaan dinilai mampu menghasilkan laba dari operasional perusahaan serta menekankan harga pokok produk dari penjualan dengan sangat efektif yang dapat dilihat dari hasil Gross Profit Margin yang berada di atas $30 \%$ selama 5 tahun terakhir.

4. Berdasarkan hasil perhitungan analisis rasio keuangan menggunakan rasio likuiditas (CR), solvabilitas (Debt to Assets Ratio), dan Rentabilitas (ROA) dapat disimpulkan bahwa kinerja PT. Ultrajaya Milk Industry \& Trading Company, Tbk. pada tahun 2013 - 
2017 sangat baik dan lebih unggul dibandingkan kedua perusahaan pembanding yaitu, PT. Mayora Indah Tbk dan PT. Indofood Sukses Makmur Tbk. Hal ini dikarenakan hasil perhitungan rasio PT. Ultrajaya Milk Industry \& Trading Company, Tbk selalu berada di atas rata-rata industry.

\section{SARAN}

A. Bagi Perusahaan

1) Dilihat dari hasil perhitungan bahwarasio likuiditas PT. Ultrajaya Milk Industry \& Trading Company Tbk. cenderung mengalami kenaikan disetiap tahunnya. Oleh karena itu, perusahaan harus lebih memperhatikan dalam pengambilan keputusan atas pinjaman jangka pendek dan jumlah aktiva yang dimiliki agar dapat etrtutupi dan tingkat likuiditas perusahaan tetap terjaga dengan baik dan bisa selalu meningkat.

2) Rasio Solvabilitas rata-ratanya sudah baik. Hal tersebut dapat dipertahankan agar menumbuhkan kepercayaan dalam pengembalian serta mendapat laba yang besar saat perekonomian sedang tinggi.

3) Rasio Rentabilitas kurang baik, sehingga perusahaan harus lebih menekankan biaya-biaya produksi agar mampu memaksimalkan keuntungan, sehingga lebih banyak para investor menanamkan sahamnya di perusahaan tersebut.

B. Bagi Peneliti

1) Bagi peneliti yang akan meneliti PT. Ultrajaya Milk Industry, Tbk. bisa lebih mengembangkan penelitian ini menggunakan analisa rasio keuangan lainnya.

\section{DAFTAR PUSTAKA}

Annisa Putri, 2016. Analisis Laporan Keuangan Pada PT. Ultrajaya Milk Industry, Tbk (Periode 2010 - 2015), Skripsi, Fakultas Ekonomi Universitas Gunadarma.

Baridwan, Zaki. 1992. Intermediate Accounting, Edisi Ketujuh. BPFE-Yogyakarta, Yogyakarta.

Bursa Efek Indonesia (BEI) www.idx.co.id, diakses tanggal 5 September 2017.

Fahmi, Irham, 2013. Analisis Laporan Keuangan, Alfabeta, Bandung.

Hanafi, Mamduh M dan Halim Abdul, 2002. Analisis Laporan Keuangan, UPP-AMP YKPN,Yogyakarta.

Harahap, Sofyan, 2002. Teori Akuntansi Laporan Keuangan, Bumi Aksara, Jakarta.

Harahap, Sofyan, 2006. Analisa Kritis Atas Laporan Keuangan, PT. Raja Grafindo Persada, Jakarta.

Ikatan Akuntansi Indonesia, 2002,StandarAkuntansi Keuangan, PSAK par. 47,Salemba Empat, Jakarta.

Ika, Nur Stantia, 2016, Analisis Kinerja Keuangan Pada PT. Ultrajaya Milk Industry \& Trading Company, Tbk. Periode 2012 - 2014,Skripsi, Fakultas Ekonomi Universitas Gunadarma, Jakarta. 
Kasmir, 2008, Analisis Laporan Keuangan, Rajawali Pers, Jakarta.

Keown,J,Arthur,et al, 2004. Dasar-dasarManajemen Keuangan, PT Indeks, Jakarta.

Margaretha, Farah, 2004. Teori dan Aplikasi Manajemen Keuangan Investasi, Jakarta.

Menteri Keuangan Republik Indonesia, 1989. Keputusan No. 740/KMK00/1989

Mulyadi, 2001. Akuntansi Manajemen: Konsep, Manfaat, dan Rekayasa, Jilid Ketiga, Bagian Penerbitan Sekolah Tinggi Ilmu Ekonomi YKPN, Jogyakarta.

Munawir, 1991. Analisa Laporan Keuangan, Liberty Yogyakarta, Yogyakarta.

Munawir, 2010. Analisa Laporan Keuangan, Edisi Keempat, Liberty, Yogyakarta.

PT. Indofood Sukses Makmur, Tbk. www.indofood.com, diakses tanggal 26 Februari 2018.

PT.Mayora Indah, Tbk. www.mayoraindah.co.id, diakses tanggal 26 Februari 2018.

PT. Ultrajaya Milk Industry \& Trading Company, Tbk. www.ultrajaya.com, diakses tanggal 5 Desember 2017.

Rudianto, 2006, Akuntansi Manajemen: Informasi untuk Pengambilan Keputusan Manajemen, Grasindo, Yogyakarta.

Simanjuntak, J., Payaman, 2005. Manajemen dan Evaluasi Kerja, Skripsi, Lembaga Fakultas Ekonomi Universitas Indonesia, Jakarta.

Sugiono, Arief, 2009,Manajemen Keuangan: Untuk Praktisi Keuangan, PT. Gramedia Widiasarana Indonesia, Jakarta.

Sundjaja Ridwan S. dan Inge Barlian, 2001, Perangkatd an Model Analisis, Literata Lintas Media, Jakarta.

Teti Chandrayanti, 2014. Analisa Kinerja Keuangan PT. Ultrajaya Milk Industry and Trading Company, Tbk Berdasarkan Metode Analisa Perbandingan Internal dan Industri (SektorMakanandanMinuman), Skripsi, Fakultas Ekonomi Universitas Ekasakti, Padang.

Wild, J. J., et.al, 2005. Analisa Laporan Keuangan, Edisi Kedelapan, Salemba Empat, Jakarta. 